\title{
ANALISIS MAQĀSIID AL-SHARI'AH TERHADAP PERAN PEMERINTAH KOTA SURABAYA DALAM MEWUJUDKAN KOTA LAYAK ANAK
}

\author{
Zakiyatul Ulya \\ UIN Sunan Ampel \\ Surabaya \\ zakiyatululya@uinsby.ac.id
}

\begin{abstract}
The research entitled: "Maqāșid alsharī'ah Analysis of the Role of the Surabaya City Government in Realizing Child Friendly Cities" is a field research that aims to answer the question how the role of the Surabaya City Government in realizing Child Friendly Cities through established public policies from the perspective of the maqāșid al-sharī'ah. Research data were collected using interview and documentation techniques and then analyzed using descriptive analysis techniques with a deductive mindset. The results of the study concluded that the Surabaya City Government was very active in realizing Child Friendly Cities through the protection and fulfillment of children's rights, which was clearly seen from the existence of various public policies that were established to support institutional strengthening and fulfillment of the five Child Friendly Cities clusters. The role of the Surabaya City Government is in accordance with the concept of maqāsid al-shari'ah because the determination of public policy is based on the welfare of children. This is proven by the elements of hifz al-din and hifz al-nasl in the public policy regarding civil rights and freedom, family environment, and alternative protection. In addition, there are elements of hifz al-nafs and hifz al-aql in public policies regarding institutional strengthening and the five Child Friendly Cities clusters, although they are actually less than perfect due to the absence of the hifz al-mal elements in them.
\end{abstract}

Keywords: Maqāṣid al-sharī'ah, Surabaya City Government, Kota Layak Anak.

Abstrak: Penelitian yang berjudul: "Analisis Maqāșid al-sharì'ah terhadap Peran Pemerintah Kota Surabaya dalam Mewujudkan Kota Layak Anak" ini merupakan penelitian lapangan (field 
research) yang bertujuan untuk menjawab pertanyaan bagaimana peran Pemerintah Kota Surabaya dalam mewujudkan Kota Layak Anak melalui kebijakan publik yang ditetapkan dari perspektif maqāșid al-sharì̄ah. Data penelitian dihimpun menggunakan teknik wawancara dan dokumentasi kemudian dianalisis menggunakan teknik analisis deskriptif dengan pola pikir deduktif. Hasil penelitian menyimpulkan bahwa Pemerintah Kota Surabaya sangat berperan aktif dalam mewujudkan Kota Layak Anak melalui perlindungan dan pemenuhan hak-hak anak yang terlihat jelas dari adanya berbagai kebijakan publik yang ditetapkan guna mendukung penguatan kelembagaan dan pemenuhan kelima kluster Kota Layak Anak. Peran Pemerintah Kota Surabaya telah sesuai dengan konsep maqāṣid al-sharī'ah karena penetapan kebijakan publik dilakukan berdasarkan pada kemaslahatan anak. Hal ini terbukti dengan terkandungnya unsur hifz al-din serta hifz al-nasl pada kebijakan publik mengenai hak sipil dan kebebasan serta lingkungan keluarga dan perlindungan alternatif. Selain itu, terdapat unsur hifz al-nafs serta hifz al-'aql pada kebijakan publik mengenai penguatan kelembagaan dan kelima kluster Kota Layak Anak, meskipun sebenarnya kurang sempurna karena ketiadaan unsur hifż al-māl di dalamnya.

Kata Kunci: Maqāșid al-Sharīah, Pemerintah

\section{Pendahuluan} Kota Surabaya, Kota Layak Anak

Anak merupakan amanah yang harus dijaga dan dilindungi oleh orang tua, bahkan oleh Negara karena anak-anak pada masa ini merupakan modal pembangunan dan kunci kemajuan bangsa di masa depan. Anak-anak itulah yang akan melanjutkan perjuangan generasi pendahulunya untuk memajukan bangsa dan negaranya. Oleh karena itu, hak-haknya harus dipenuhi agar dapat menjadi generasi yang unggul. Kewajiban Negara tersebut sebenarnya telah tertuang dalam pasal 28 b UUD 1945 yang berbunyi: "Setiap anak berhak atas kelangsungan hidup, 
tumbuh, dan berkembang serta berhak atas perlindungan dari kekerasan dan diskriminasi". ${ }^{1}$

Beberapa prinsip hak-hak anak telah ditetapkan dalam Konveksi Hak-hak Anak (Convention on the Rights of the Child) pada tanggal 20 November 1989 melalui Sidang Umum PBB dan juga telah diatur dalam Undang-undang Nomor 23 Tahun 2002 jo. Undang-undang Nomor 35 Tahun 2014 tentang Perlindungan Anak yaitu:

1. Non diskriminasi;

2. Kepentingan terbaik untuk anak;

3. Hak hidup, kelangsungan hidup dan tumbuh kembang anak;

4. Penghormatan atas pandangan anak. ${ }^{2}$

Dalam Undang-undang tersebut disampaikan juga bahwa orang tua, keluarga, masyarakat, Pemerintah Daerah, Pemerintah serta Negara memiliki kewajiban dalam memberi perlindungan serta menjamin terpenuhinya hak asasi anak sesuai tugas dan tanggung jawab masing-masing. Adapun anak sendiri didefinisikan sebagai seseorang yang belum mencapai usia delapan belas tahun, termasuk juga anak dalam kandungan. ${ }^{3}$

Sebagai bentuk upaya pemenuhan hak anak, pemerintah harus segera mewujudkan Kota Layak Anak (KLA) yang yaitu sebuah kabupaten/kota yang memiliki sistem pembangunan berbasis anak melalui adanya integrasi komitmen dan sumber daya pemerintah, masyarakat serta dunia usaha yang terencana secara menyeluruh dan berkelanjutan dalam kebijakan, program dan kegiatan untuk menjamin terpenuhinya hak anak. ${ }^{4}$

\footnotetext{
${ }^{1}$ Pasal 28b Undang-undang Dasar 1945 (Perubahan Kedua).

${ }^{2}$ Margono-Surya $\quad$ Partners, "Perlindungan Anak, dalam file:///D:/Penelitian\%20Baru/Margono\%20 \%20Surya\%20\&\%20Partners\%20Pe rlindungan\%20Anak\%20-\%20Margono\%20 \%20Surya\%20\&\%20Partners.html, diakses pada 17 September 2018.

${ }^{3}$ Undang-undang Nomor 35 Tahun 2014 tentang Perubahan Atas Undang-undang Nomor 23 Tahun 2002 tentang Perlindungan Anak.

4 Pasal 1 ayat 3 Peraturan Menteri Negara Pemberdayaan Perempuan dan Perlindungan Anak Republik Indonesia tentang Kebijakan Pengembangan Kabupaten/Kota Layak Anak.
} 
Tujuan pembangunan KLA adalah menumbuhkan inisiatif pemerintah kabupaten/kota menuju upaya transformasi konvensi hak-hak anak dari kerangka hukum ke dalam definisi, strategi dan intervensi pembangunan yang berupa kebijakan, program serta kegiatan pembangunan, dalam upaya pemenuhan hak anak di suatu dimensi wilayah kabupaten/kota. Indikatornya tidak lain berupa tersedianya pemenuhan atas hak anak di segala bidang sebagai warga kota, dapat berperan dan berpartisipasi aktif dalam perencanaan dan pembangunan kota sesuai kemampuan dan kebutuhan anak. ${ }^{5}$

Secara garis besar terdapat 24 indikator KLA yang tecakup pada penguatan Kelembagaan serta kelima kluster: kluster I (Hak Sipil dan Kebebasan), kluster II (Lingkungan Keluarga dan Pengasuhan Alternatif), kluster III (Kesehatan Dasar dan Kesejahteraan), kluster IV (Pendidikan, Pemanfaatan Waktu Luang dan Kegiatan Budaya), serta kluster V (Perlindungan Khusus). ${ }^{6}$

Adapun dalam upaya mempercepat terwujudnya KLA di seluruh Indonesia, Kementerian Pemberdayaan Perempuan dan Perlindungan Anak (KPP-PA) memiliki sebuah program yang bertujuan untuk mewujudkan Indonesia Layak Anak (IDOLA) 2030 berupa pemberian penghargaan KLA kepada kota/kabupaten yang memenuhi 24 indikator penilaian yang ditetapkan oleh KPP-PA sebagaimana yang telah disebutkan sebelumnya. ${ }^{7}$ Dengan adanya program ini, seluruh kabupaten/kota di Indonesia berlomba-lomba untuk memperbaiki kualitas pemenuhan hak-hak anak di daerahnya masing-masing demi mendapatkan predikat sebagai KLA.

Salah satu kota yang beberapa kali telah berhasil mendapatkan penghargaan KLA tersebut adalah Kota Surabaya,

5 Investor Daily Indonesia, "Membangun Kota Layak Anak", dalam http://id.beritasatu.com/home/membangun-kota-layak-anak/16543, diakses pada 17 September 2018.

${ }^{6}$ Amdany Praptama (Staf Bidang Pengarusutamaan Hak Anak (Puha) DP5A Kota Surabaya), Wawancara, Surabaya, 1 Oktober 2019.

7 Okezone News, "Surabaya dan Solo Pertahankan Gelar Kota Layak Anak", dalam https://news.okezone.com/read/2018/07/24/1/1926501/surabaya-dan-solopertahankan-gelar-kota-layak-anak, diakses pada 17 September 2018. 
termasuk yang terbaru yaitu pada tahun 2019. Hal ini tentu sesuatu yang luar biasa, dimana Kota Surabaya merupakan kota terbesar serta tertua di Indonesia dengan total luasnya sebesar 330. $45 \mathrm{~km}$ dengan jumlah penduduk lebih dari 3 juta orang pada malam hari dan lebih dari 5 juta orang pada jam kerja. Surabaya sendiri terletak di bagian timur laut Pulau jawa dengan Tanjung Perak sebagai Pelabuhan utamanya yang memiliki fungsi sebagai penghubung atau pusat pengiriman antar pulau di wilayah Indonesia bagian timur. ${ }^{8}$

Jumlah penduduk Surabaya yang terus mengalami peningkatan yang sangat pesat pada setiap tahunnya menyebabkan berbagai permasalahan, terutama permasalahan anak, baik permasalahan di bidang pendidikan maupun kesenjangan sosial, yang akhir-akhir ini menjadi salah satu perhatian khusus Pemerintah Kota Surabaya untuk segera diselesaikan. Berbagai upaya dilakukan guna menangani permasalahan tersebut dan menjadikan Surabaya sebagai Kota Layak Anak mulai dari penyediaan berbagai fasilitas untuk anak hingga penyelesaian masalah anak yang terlibat kasus hukum. ${ }^{9}$

Dari pemaparan di atas, terlihat jelas bahwa Pemerintah Kota Surabaya tidak lantas menyerah ketika berhadapan dengan berbagai permasalahan yang ada, namun terus berupaya membuat beberapa gebrakan baru agar hak-hak anak dapat terwujud. Adapun beberapa gebrakan yang dimaksud antara lain berupa penutupan Dolly pada tahun 2015, pembangunan perpustakaan di setiap RW disertai pendampingan dari tenaga profesional, pembangunan lahan kosong menjadi berbagai macam lapangan olahraga, penataan taman umum dengan fasilitas ramah anak juga wifi gratis, penugasan Satpol PP setiap

\footnotetext{
8 Pemerintah Kota Surabaya, "The History of Surabaya", dalam https://sparkling.surabaya.go.id/about/the-history-of-surabaya/, diakses pada 04 April 2020.

9 Koran Jakarta, "Upaya Risma Jadikan Surabaya Kota Layak Anak, dalam http://www.koran-jakarta.com/upaya-risma-jadikan-surabaya-kota-layak-anak/, diakses pada 29 Mei 2019.
} 
malam guna melakukan pengawasan terhadap anak-anak di bawah umur serta masih banyak lainnya. ${ }^{10}$

Beberapa gebrakan tersebut tidak serta merta dilakukan tanpa adanya dasar kebijakan dengan arti Pemerintah Kota Surabaya telah memiliki beberapa peraturan dalam melindungi dan memenuhi hak-hak anak sebagai bagian dari warga Indonesia, baik berupa Peraturan Daerah, Peraturan Walikota maupun Surat Keputusan Walikota. Sebagai salah satu contohnya adalah Peraturan Daerah Kota Surabaya Nomor 6 Tahun 2011 tentang Penyelenggaraan Perlindungan Anak. Adapun dalam menetapkan serta melaksanakan sebuah kebijakan dan progam, Pemerintah Kota Surabaya terlebih dahulu akan melaksanakan analisis yang mendalam terkait kebaikan dan kemanfaatan yang dapat diwujudkan untuk warganya. ${ }^{11}$

Dari uraian mengenai peran Pemerintah Kota Surabaya dalam Mewujudkan Kota Layak Anak di atas, dapat dilihat dari aspek perwujudan regulasi hingga penyusunan progam guna terpenuhi dan terlindunginya hak-hak anak. Adapun bentuk regulasi yang telah disusun oleh Pemerintah Kota Surabaya antara lain berupa Peraturan Daerah, Peraturan Walikota maupun Surat Keputusan Walikota. Berbagai kebijakan publik yang ditetapkan oleh Pemerintah Kota Surabaya untuk mewujudkan Kota Layak Anak tersebut perlu diuji dari perspektif maqāșid al-sharīah terkait dengan kemaslahatan bersama yang harus diwujudkan.

Dalam hukum Islam dikenal istilah maqāșid al-sharīah (tujuan hukum Islam) atau maqasid al-tashri' (tujuan pembentukan hukum Islam) yang merupakan pembahaan penting pada hukum Islam yang tidak luput dari dari perhatian para ulama maupun pakar hukum Isam. Sebagian dari mereka memasukkannya ke dalam pembahasan ushul Fikih dan

10 Parenting Indonesia, "Mengintip Surabaya Kota Layak Anak", dalam http://www.parenting.co.id/keluarga/mengintip-surabaya-kota-layak-anak-, diakses pada 17 September 2018.

${ }^{11}$ Amdany Praptama (Staf Bidang Pengarusutamaan Hak Anak (Puha) DP5A Kota Surabaya), Wawancara, Surabaya, 1 Oktober 2019. 
sebagian dari yang lain menjadikannya pembahasan tersendiri serta memperluasnya dalam filsafat hukum Islam. Akan tetapi, dalam hal ini dapat disimpulkan bahwa pembahasan maqāșid alsharī'ah/maqāșid al-tashrī' dapat ditemukan dalam baik dalam pembahasan ushul fikih maupun filsafat hukum Islam. ${ }^{12}$

Pembahasan mengenai maqāșid al-sharī'ah tersebut secara khusus, sistematis dan jelas telah dilakukan oleh alShatibi dalam kitabnya yang berjudul: "Al-Muwāfaqāt" dengan mengungkapkan bahwa tujuan Allah menetapkan hukum yaitu agar terwujudnya kemaslahatan hidup manusia, baik di dunia maupun akhirat. Oleh karena itu, taklif hukum harus mengarah pada realisasi tujuan hukum tersebut.13 Maqāșid al-sharī'ah juga diartikan oleh sebagian ulama ushul sebagai tujuan yang dikehendaki dalam pensyariatan hukum bagi kemaslahatan umat manusia dan ada yang menyebutnya sebagai asrār alsharī'ah (rahasia-rahasia dibalik hukum yang disyari'atkan).

Secara umum, maslahat sendiri terbagi menjadi dua bentuk:

1. Mewujudkan kemanfaatan dan kebaikan bagi manusia, baik yang dapat dirasakan secara langsung atau tidak langsung ketika melakukan perbuatan yang diperintahkan (jalb almasālih̆/jalb al-manāfi').

2. Menghindari/mencegah kerusakan dan keburukan, baik yang dirasakan saat berbuat atau setelahnya (dar' almafāsid). ${ }^{14}$

Adapun Maslahah sebagai substansi maqāșid al-sharī'ah dapat dibagi menjadi tiga tingkatan berikut:

1. Darüriyāt, yaitu maslahah yang bersifat primer, yang jika ditinggalkan akan menyebabkan kerusakan bagi kehidupan manusia.

2. Hajiyāt, yaitu maslahah yang bersifat sekunder, yang jika ditinggalkan manusia akan mengalami kesulitan pada

\footnotetext{
${ }^{12}$ Amir Syarifuddi, Ushul Fiqh, jilid 2 (Jakarta: Kencana, 2011), 220.

${ }^{13}$ Ghofar Shidiq, “Teori Maqashid al-Syari'ah dalam Hukum Islam”..., 122.

${ }^{14}$ Maman Suherman, "Aliran Ushul Fiqh dan Maqashid Syari'ah”, Al Mahlahah Jurnal Hukum dan Pranata Sosial Islam (2017), 362.
} 
hidupnya dengan arti tidak sampai menimbulkan kerusakan.

3. Tahsiniyāt, yaitu maslahah yang bersifat tersier, yang jika ditinggalkan tidak akan menimbulkan kerusakan atau kesulitan pada hidup manusia, namun akan keluar dari tuntutan menjadi manusia yang bermartabat. ${ }^{15}$

Di setiap tingkatannya, terdapat lima unsur pokok, yang sering disebut dengan usūl al-khamsah, dan harus dijaga atau dipelihara guna mewujudkan kemaslahatan, yang berupa hifz aldin (memelihara agama), hifz al-nafs (memelihara jiwa), hifz al'aql (memelihara akal), hifz al-nasl (memelihara keturunan), hifz al-mal (memelihara harta). ${ }^{16}$ Hal ini mencakup pengertian bahwa seorang mujtahid, qadi atau pihak lain yang berwenang dalam menetapkan hukum harus berdasar pada kelima unsur pokok di atas agar dapat mewujudkan kemaslahatan untuk masyarakat pada umumnya.

Berdasarkan gambaran di atas, maka dirasa penting untuk melakukan penelitian lebih lanjut dengan judul "Analisis Maqāṣid al-sharī'ah terhadap Peran Pemerintah Kota Surabaya dalam Mewujudkan Kota Layak Anak" yang bertujuan untuk menguji peran Pemerintah Kota Surabaya dalam mewujudkan Kota Layak Anak melalui kebijakan publik yang ditetapkan dari perspektif maqāșid al-sharī'ah sehingga dapat diketahui sesuai tidaknya peran Pemerintah Kota Surabaya dalam mewujudkan Kota Layak Anak melalui kebijakan publiknya tersebut menggunakan konsep maqāșid al-sharī'ah dalam Islam yang merupakan pedoman yang harus dipegang dalam penetapan kebijakan.

Penelitian mengenai Kota Layak Anak bukanlah pertama kali dilakukan, dalam arti telah ada beberapa penelitian sejenis yang dihasilkan sebelumnya, yaitu: "Implementasi Kebijakan Kota Layak Anak (Studi Deskriptif Tentang Kluster

15 'Abd al-Wahhab Khallaf, 'Ilm Usul al-Fiqh, terj. Faiz el Muttaqin (Jakarta: Pustaka Amani, 2003), 302-303.

16 Ridwan Jamal, "Maqashid al-Syari'ah dan Relevansinya dengan Konteks Kekinian”, Al-Syir'ah, Vol. 8, No. 1 (2010), 7. 
Perlindungan Khusus di Kota Surabaya)",17 "Implementasi Kebijakan Pengembangan Kota Layak Anak di Kecamatan Semampir Surabaya",18 "Implementasi Kebijakan Pengarusutamaan Hak Anak dalam Rangka Mewujudkan Kabupaten Layak Anak (Studi pada Badan Pemberdayaan Perempuan dan Keluarga Berencana Kabupaten Jombang)",19 "Inovasi Pelayanan Lamongan sebagai Kota Layak Anak", ${ }^{20}$ dan "Partisipasi Masyarakat dalam Mewujudkan Kampung Ramah Anak Melalui Program Inisiasi Kampunge Arek Suroboyo (KAS) di Kelurahan Jambangan Kecamatan Jambangan Kota Surabaya (Studi Pada Rt 7 Dan Rt 8 Rw 3 Kelurahan Jambangan Kecamatan Jambangan Kota Surabaya)". 21

Meskipun memiliki tema penelitian sama, yaitu mengenai Kota Layak Anak, namun fokus pembahasannya berbeda yang mana penelitian pertama sampai ketigahanya terfokus pada implementasi kebijakan yang bersifat parsial, apalagi objek kajian penelitian ketiga menggunakan kabupaten. Adapun penelitian keempat dan kelima, meskipun fokusnya hampir sama, yaitu mengenai pelayanan pemerintah daerah, namun berbeda juga dalam objek kajiannya, yaitu antara Surabaya dan Lamongan pada penelitian keempat serta antara masyarakat dan pemerintah daerah pada penelitian kelima. Adanya perbedaan antara penelitian yang akan dibahas dengan

\footnotetext{
${ }^{17}$ Miftakhul Prastya Kurniawan, "Implementasi Kebijakan Kota Layak Anak (Studi Deskriptif Tentang Kluster Perlindungan Khusus di Kota Surabaya)" (Skripsi--Universitas Airlangga, 2016).

${ }^{18}$ Faradilla Nissa Safitri, "Implementasi Kebijakan Pengembangan Kota Layak Anak di Kecamatan Semampir Surabaya”, Publika, No. 3, Vol. 4 (2013).

${ }^{19}$ Merdina Kusumastuti, "Implementasi Kebijakan Pengarusutamaan Hak Anak dalam Rangka Mewujudkan Kabupaten Layak Anak (Studi Pada Badan Pemberdayaan Perempuan dan Keluarga Berencana Kabupaten Jombang)", Jurnal Administrasi Publik, No. 6, Vol. 1 (2013).

20 Dialistiowati, "Inovasi Pelayanan Lamongan Sebagai Kota Layak Anak" (Skripsi--UIN Sunan Ampel Surabaya, 2017).

${ }^{21}$ Aisyah, "Partisipasi Masyarakat dalam Mewujudkan Kampung Ramah Anak melalui Program Inisiasi Kampunge Arek Suroboyo (Kas) di Kelurahan Jambangan Kecamatan Jambangan Kota Surabaya (Studi Pada Rt 7 dan Rt 8 Rw 3 Kelurahan Jambangan Kecamatan Jambangan Kota Surabaya)", Publika, No. 3, Vol. 5 (2017).
} 
penelitian terdahulu juga semakin jelas dari segi pisau analisis yang digunakan, yang mana tidak digunakannya konsep maqasid al-shari'ah sebagai pisau analisis pada penelitian terdahulu. Dengan demikian, dapat disimpulkan bahwa penelitian yang dibahas bukan merupakan hasil plagiasi dari penelitian terdahulu karena perbedaan objek penelitian dan pisau analisis yang digunakan.

\section{Gambaran Umum Kabupaten/Kota Layak Anak}

Kabupaten/Kota Layak Anak atau disingkat dengan KLA merupakan kabupaten/kota basisnya adalah hak anak dalam sistem pembangunannya berupa integrasi komitmen dengan sumberdaya pemerintah, masyarakat serta dunia usaha secara menyeluruh, terencana dan berkelanjutan pada kebijakan, program dan kegiatan dalam penjaminan dan pemenuhan hak anak. ${ }^{22}$ Terdapat 24 indikator yang harus dipenuhi agar mendapatkan predikat KLA sebagai berikut:

1. Kelembagaan, yang meliputi beberapa indikator berupa ketersediaan kebijakan/peraturan daerah tentang KLA, keterlembagaan KLA, keterlibatan lembaga masyarakat, dunia usaha dan media massa dalam pemenuhan dan perlindungan hak anak. ${ }^{23}$

2. Klaster, yang terdiri dari lima kluster yaitu:

a. Kluster I (Hak Sipil dan Kebebasan), yang meliputi beberapa indikator berupa presentase anak yang diregistrasi dan memperoleh kutipan akta kelahiran, ketersediaan fasilitas ILA, serta keterlembagaan partisipasi anak.

b. Kluster II (Lingkungan Keluarga dan Pengasuhan Alternatif), yang meliputi beberapa indikator berupa presentase perkawinan anak, ketersediaan lembaga konsultasi penyedia layanan pengasuhan anak bagi orang tua/keluarga, lembaga pengasuhan alternatif terstandarisasi, PAUD-HI, serta ketersediaan sarana

\footnotetext{
${ }^{22}$ Kla.id, "Definisi KLA dan Kluster", dalam http://www.kla.id/, diakses pada 01 Oktober 2019.

${ }^{23}$ Amdany Praptama (Staf Bidang Pengarusutamaan Hak Anak (Puha) DP5A Kota Surabaya), Wawancara.
} 
dan prasarana yang ramah anak di ruang publik.

c. Kluster III (Kesehatan Dasar dan Kesejahteraan), yang meliputi beberapa indikator berupa presentase persalinan di fasilitas pelayanan kesehatan, prevalansi status gizi balita, cakupan PMBA usia di bawah 2 tahun, fasilitas PRAP, rumah tangga dengan akses air minum dan sanitasi yang layak, ketersediaan kawasan tanpa rokok dan tanpa iklan, promosi serta sponsornya.

d. Kluster IV (Pendidikan, Pemanfaatan Waktu Luang dan Kegiatan Budaya), yang meliputi beberapa indikator berupa presentase Wajib Belajar 12 Tahun, Sekolah Ramah Anak (SRA) serta tersedianya fasilitas kegiatan budaya, kreatifitas serta rekreatif yang ramah anak.

e. Kluster V (Perlindungan Khusus), yang meliputi beberapa indikator berupa: tersedianya kebijakan/peraturan daerah, upaya pencegahan, penyediaan layanan, penguatan dan pengembangan lembaga, Situasi darurat dan pornografi anak korban bencana dan konflik yang terlayani (HIV-AIDS, dan Napza), Kasus ABH khusus pelaku yang terselesaikan, anak korban jaringan terorisme, stigmatisasi akibat pelabelan terkait konsisi orang tua yang terlayani; Anak peyandang disabilitas, kelompok minoritas serta terisolasi yang terlayani, anak dengan perilaku sosial menyimpang serta perlindunganan anak dari KTA BPTA, Seksual, Perdagangan serta Kejahatan Seksual. ${ }^{24}$

\section{Kebijakan Publik yang Ditetapkan oleh Pemerintah Kota Surabaya dalam Mewujudkan Kota Layak Anak}

Adapun dalam rangka melaksanakan perannya dalam mewujudkan Kota Layak Anak, berbagai kebijakan publik telah ditetapkan oleh Pemerintah Kota Surabaya dengan rincian:

1. Kelembagaan

a. Memiliki beberapa peraturan penguatan kelembagaan Kota Layak Anak di antaranya Peraturan Daerah Kota

${ }^{24}$ Kementerian Pemberdayaan Perempuan dan Perlindungan Anak, Petunjuk Teknis Indikator Kabupaten/Kota Layak Anak 2019 (Jakarta: Kementerian Pemberdayaan Perempuan dan Perlindungan Anak, 2019). 
Surabaya tentang Penyelenggaraan Perlindungan Anak, tentang Penyelenggaraan Pendidikan, tentang Upaya Kesehatan, tentang Penyelenggaraan Administrasi Kependudukan, dan tentang Penyelenggaraan Kesejahteraan Sosial.

b. Memiliki beberapa progam dalam rangka penguatan kelembagaan Kota Layak Anak berupa:

1) Pengalokasian APBD Kota Surabaya dalam rangka pelaksanaan program penguatan kelembagaan Kota Layak Anak.

2) Pelibatan FAS (Forum Anak Surabaya) dalam berbagai kegiatan termasuk penyusunan kebijakan daerah.

3) Pembentukan Gugus Tugas Surabaya Kota Layak Anak. ${ }^{25}$

4) Pendeklarasikan 154 Desa/Kelurahan Layak Anak (Dakela) dan 31 Kecamatan Layak Anak (Kelana).

5) Kampanye Perlindungan Anak, Poster larangan keluar malam, dan Sosialisasi Dinamika Remaja.

2. Kluster I: Hak Sipil dan Kebebasan

a. Memiliki peraturan beberapa peraturan yang memuat tentang hak sipil dan kebebasan di antaranya Peraturan Daerah Kota Surabaya tentang Penyelenggaraan Administrasi Kependudukan, tentang Penyelenggaraan Perlindungan Anak dan Peraturan Walikota Surabaya tentang Layanan Informasi Layak Anak. ${ }^{26}$

b. Memiliki beberapa program dalam mewujudkan hak sipil dan kebebasan berupa:

1) Pengalokasian APBD pada program yang bertujuan untuk mewujudkan hak sipil dan kebebasan.

2) Penyelenggaraan administrasi kependudukan secara gratis bahkan pengantaran ke rumah sakit/rumah, dan pengurusan melalui mobile/internet.

3) Pengaturan mekanisme registrasi kelahiran yang

25 Ibid.

${ }^{26}$ Dokumen Jawaban Evaluasi Kota Layak Anak Surabaya. 
sangat mudah dengan hanya perlu untuk ke kelurahan saja atau dengan mengakses Aplikasi Kependudukan dan Pencatatan Sipil Kota Surabaya.

4) Penyediaan berbagai fasilitas ILA yang meliputi Mobil perpustakaan, layanan TBM (Taman Baca Masyarakat), Rumah Pintar, dan pengawasan warung internet.

5) Pembentukan FAS di setiap kelurahan dan Kecamatan yang ada di Surabaya.

6) Penyediaan Layanan Telepon Sahabat Anak (TeSa) dengan beragam macamnya, Sosialisasi Dinamika Remaja, serta berbagai Layanan Curhat dan Edukasi. ${ }^{27}$

3. Kluster II: Lingkungan Keluarga dan Pengasuhan Alternatif a. Memiliki beberapa peraturan yang memuat tentang lingkungan keluarga dan pengasuhan alternatif berupa Peraturan Daerah Kota Surabaya tentang Penyelenggaraan Perlindungan Anak tentang Penyelenggaraan Pendidikan, tentang Penyelenggaraan PAUD, tentang Penyelenggaran Kesejahteraan Sosial, Peraturan Walikota Liponsos Kalijudan dan tentang Kampung Anak Negeri serta Keputusan Walikota Surabaya tentang Tim Pembinaan Keluarga Sejahtera dan Puspaga Kota Surabaya, tentang PPTP2A (Pusat Pelayanan Terpadu Perlindungan Perempuan dan Anak) Kota Surabaya.

b. Memiliki program dalam mewujudkan lingkungan keluarga dan pengasuhan alternatif berupa:

1) Pengalokasian APBD untuk program yang bertujuan untuk mewujudkan lingkungan keluarga dan pengasuhan alternatif.

2) Pencegahan perkawinan anak dengan berbagai upaya di antaranya pemberian bantuan pendidikan dan modal untuk yang tidak mampu, pelatihan keterampilan anak remaja, Kampanye peduli anak, Sosialisasi Dinamika Remaja dan lain sebagainya.

${ }^{27}$ Ibid. 
3) Pelaksanaan Suscatin (Program Pembinaan Khusus Calon Pengantin).

4) Pelaksanaan Program Huring (Shalat Dhuhur Keliling) atau berupa Majlis taklim setelah maghrib yang dilaksanakan per kecamatan guna pembinaan moral dan keagamaan. ${ }^{28}$

5) Penyediaan berbagai Lembaga Konseling Keluarga, di antaranya PPTP2A, Puspaga, Satgas PPA, Command Center, Pusat Krisis Berbasis Masyarakat dan lain sebagainya. ${ }^{29}$

6) Pembentukan PAUD HI minimal 1 pos setiap RW di 154 Kelurahan yang ada di Surabaya dengan programnya berupa pemberian makanan tambahan bagi peserta didik PPT dan penyediaan layanan inklusi.

7) Penyediaan Lembaga Pengasuhan Alternatif yang terstadarisasi, misalnya Shelter PPTP2A Kota Surabaya, Liponsos Kalijudan, LPAS, serta KANRI (Kampung Anak Negeri).

8) Penyediaan RBRA (Ruang Bermain Ramah Anak) berupa taman dan lapangan tempat olahraga yang dapat dimanfaatkan oleh semua anak termasuk penyandang disabilitas.

9) Penyediaan RASS (Rute Aman Selamat Ke Dan Dari Sekolah) dengan beberapa fasilitas untuk pejalan kaki di sekitar sekolah termasuk fasilitas tambahan untuk penyandang disabilitas.

4. Kluster III: Kesehatan Dasar dan Kesejahteraan

a. Memiliki beberapa peraturan yang memuat tentang kesehatan dasar dan kesejahteraan berupa Peraturan Daerah Kota Surabaya tentang Upaya Kesehatan, tentang Penyelenggaraan Perlindungan Anak, tentang Pengelolaan Kualitas Air dan Pengendalian Air Limbah, tentang Kawasan Tanpa Rokok dan Kawasan Terbatas

\footnotetext{
${ }^{28}$ Ibid.

${ }^{29}$ Fatchul Munir (Tim Pembina Keluarag Puspaga (Pusat Pembelajaran Keluarga) DP5A Kota Surabaya), Wawancara, Surabaya, 4 Oktober 2019.
} 
Merokok dan Peraturan Walikota Surabaya tentang Petunjuk Teknis Pemberian Pelaayanan Jaminan Kesehatan Masyarakat dan Jaminan Persalinan oleh Dinas Kesehatan Kota serta Surat Edaran Walikota Surabaya tentang Gerakan Masyarakat Hidup Sehat. ${ }^{30}$

b. Memiliki beberapa program dalam mewujudkan Kesehatan Dasar dan Kesejahteraan berupa:

1) Pengalokasian APBD untuk program yang bertujuan mewujudkan kesejatan dasar dan kesejahteraan.

2) Pengadaan beragam pelatihan, seminar, sosialisasi serta pemantauan untuk ibu hamil di Surabaya.

3) Penanggulangan permasalahan gizi dengan berbagai kegiatan mulai dari pendampingan 1000 Hpk sampai pada audit gizi buruk.

4) Penyediaan Ruang ASI (Pojok Laktasi) yang tersebar pada fasilitas umum dan instansi kerja, RSSIB (Rumah Sakit Sayang Ibu dan Bayi), adanya konselor ASI dan PMBA di setiap kelurahan.

5) Melakukan berbagai upaya peningkatan akses penyediaan air minum dalam rumah tangga antara lain berupa Kampanye, Wisata Edukasi, Roadshow Sekolah, Mural Dinding dan penyuluhan.

6) Mensosialisasikan kebijakan Kawasan Tanpa Rokok kepada Masyarakat beserta sanksinya dan Penyediaannya di berbagai fasilitas.

7) Mensosialisasikan bahaya merokok pada anak Surabaya, melakukan pembinaan KTR serta menyediakan ruang khusus untuk merokok.

5. Kluster IV: Pendidikan, Pemanfaatan Waktu Luang dan Kegiatan Budaya

a. Memiliki berbagai peraturan yang memuat tentang Pendidikan, Pemanfaatan Waktu Luang dan Kegiatan Budaya berupa Peraturan Daerah Kota Surabaya tentang Penyelenggaraan Pendidikan, Penyelenggaraan Perlindungan Anak, tentang Kawasan Tanpa Rokok dan

${ }^{30}$ Dokumen Jawaban Evaluasi Kota Layak Anak Surabaya.

\section{AL-HUKAMA'}


Kawasan Terbatas Merokok, tentang Penyelenggaraan dan Pengelolaan Perpustakaan, tentang Penyelenggaraan Pendidikan, tentang Perlindungan Pohon, tentang Retribusi Tempat Rekreasi dan Olahraga, tentang Kepariwisataan dan Peraturan Walikota Surabaya tentang Penyelenggaraan dan Pengelolaan Pendidikan di Kota Surabaya. ${ }^{31}$

b. Memiliki beberapa program dalam mewujudkan pendidikan, pemanfaatan waktu luang dan kegiatan budaya berupa:

1) Pengalokasian APBD untuk program yang bertujuan mewujudkan pendidikan, pemanfaatan waktu luang dan kegiatan budaya.

2) Pelatihan konvensi hak anak SDM Penyelenggara Program Wajib Belajar 12 Tahun melalui kegiatan Konselor Sebaya.

3) Pengadaan program BLC (Board Learning Center) guna membekali pengetahuan tentang IT.

4) Pembinaan baik berupa pedidikan formal maupun informal yang salah satunya dilakukan di tempat penampungan (Kampung Anak Negeri).

5) Mensosialisasikan Dinamika Remaja di Beberapa SMP baik negeri maupun swasta

6) Penyediaan Lembaga Pengasuhan Alternatif guna pemenuhan hak atas pendidikan serta sebagai tempat perlindungan dan pembinaan terhadap perilaku negatif.

7) Penyediaan tempat penampungan guna pemenuhan hak atas pendidikan berupa Liponsos Kalijudan untuk ABK serta Kampung Anak Negeri untuk anak putus sekolah, terlantar dan anak jalanan.

8) Mewujudkan Sekolah Ramah Anak (SRA) serta membinanya dengan cara mengadakan sosialisasi Dinamika Remaja, pelatihan siswa, pembinaan minta bakat dan lain sebagainya.

31 Ibid. 
9) Pembentukan PKA (Pusat Kreatifitas Anak) di Kota Surabaya yang dapat diakses secara gratis oleh semua anak tanpa terkecuali.

6. Kluster V: Perlindungan Khusus

a. Memiliki beberapa peraturan yang memuat tentang Perlindungan Khusus berupa Peraturan Daerah Kota Surabaya tentang Penyelenggaraan Perlindungan Anak, tentang Penyelenggaraan Ketertiban Umum dan Ketentraman Masyarakat, tentang Pencegahan dan Penanganan Korban Perdagangan Orang, tentang Penanggulangan HIV/AIDS, Penyelenggaran Kesejahteraan Sosial, Peraturan Walikota Surabaya Tentang Pedoman Penanggulangan Bencana Saat Tanggap Darurat di Kota Surabaya, serta Keputusan Walikota Surabaya tentang Tim PPTP2A Kota Surabaya, Tim Pembinaan dan Pengawasan terhadap Sarana dan Pelayanan Kesehatan di Kota Surabaya, Komisi Penanggulangan AIDS Kota Surabaya, Satuan Pelaksana Penanggulangan Bencana dan Satuan Tugas Satuan Pelaksana Penanggulangan Bencana Kota Surabaya. ${ }^{32}$

b. Memiliki beberapa program dalam mewujudkan Perlindungan Khusus berupa:

1) Pengalokasian APBD untuk progam yang bertujuan mewujudkan perlindungan khusus

2) Penyediaan lembaga layanan untuk anak korban kekerasan dan penelantaran serta korban pornografi di antaranya PPTP2A Kota Surabaya, 63 Puskesmas se Surabaya, Shelter, LPAS, Puspaga dan lain sebagainya.

3) Pembinaan melalui Kampunge Arek Surabaya dan Kampung Anak Negeri.

4) Pembentukan kader anti kenakalan remaja dan konselor sebaya serta Puspaga (Pusat Pembelajaran Keluarga)

5) Penyediaan lembaga bagi anak yang ditarik dari pekerjaan terburuk diantaranya PPTP2A dan

${ }^{32}$ Ibid. 
Shelternya.

6) Pelaksanaan Razia Pekerja Anak oleh Satpol PP guna pengawasan dan pencegahan terjadinya pekerja anak di Kota Surabaya.

7) Penyediaan lembaga layanan korban penyalahgunaan Napza, di antaranya BNN Kota Surabaya, lembaga layanan PTRM (Program Terapi Rumatan Metadon) dan lain sebagainya.

8) Penyediaan sistem pelaporan dan pencatatannya anak korban kekerasan, pornografi, bencana dan konflik serta sejenisnya melalui Simfoni PPA, eoutreach, e-kekerasan, e-wadul, media center serta command center.

9) Penyediaan lembaga layanan bagi anak yang terinfeksi HIV/AIDS berupa pelayanan pemeriksaan di 63 Puskesmas sesurabaya dan $7 \mathrm{di}$ antaranya melayani perawatan bagi yang positif terinfeksi HIV/AIDS (termasuk dalam hal ini, beberapa Rumah Sakit di Surabaya). ${ }^{33}$

10) Melakukan kampanye perlindungan anak serentak di 19 titik Kota Surabaya, Sosialisasi Camat serta Deteksi Dini Bahaya Narkoba. Pemeriksaan dan perawatan, pendampingan psikososial, pemberian makanan tambahan (PMT); Sosialisasi Dinamika Remaja serta Program KP KAS (Kampung Pendidikan Kampunge Arek Surabaya) serta pendampingan psikologi; P4GN (Tes Urin di SMP serta Sosialisasi Pencegahan Narkoba serta penerjunan Tim Odong-Odong dan Asuhan Rembulan guna merazia Kawasan Surabaya.

11) Penyediaan lembaga layanan bagi anak korban bencana dan konflik sebagaimana lembaga layanan yang berlaku bagi anak korban pornografi ditambah dengan PPT (Posko terpadu wilayah Surabaya) serta beberapa bantuan sosial dan penampungan.

${ }^{33}$ Ibid. 
12) Pembentukan Sekolah atau Madrasah Siap Bencana yang dilakukan oleh Satlak PB.

13) Penyedian Jalur Evakuasi Ramah Anak yang disediakan di berbagai fasilitas umum di beberapa kampung yang ada di Surabaya serta lain sebagainya.

14) Melakukan berbagai upaya guna meningkatkan kesejahteraan anak penyandang disabilitas diantaranya dengan penyediaan lembaga layanan bagi anak penyandang disabilitas, sosialisasi dan pelatihan orang tua, berbagai bantuan dan lain sebagainya.

15) Pemberian kesempatan, partisipasi dan apresiasi untuk anak penyandang disabilitas di antaranya dengan pelibatan dalam forum anak dan penyedian beasiswa bagi mereka yang berprestasi.

16) Pembuatan LPAS (Shelter), KANRI, Liponsos Kalijudan, PPTP2A dan melakukan kerjasama pendampingan hukum ABH dengan SCCC, dengan lembaga Swadaya Masyarakat di dalam penanganan anak.

17) Penguatan pendidikan Pancasila dan rasa cinta tanah air guna pencegahan anak menjadi korban jaringan terorisme di antaranya dengan dengan Sekolah Kebangsaan maupun City Tour Surabaya Heritage.

18) Pencegahan serta penanganan dan rehabilitasi anak korban stigmatisasi atas kondisi orang tuanya dengan Konselor Sebaya dan pemberdayaan karang taruna serta pencatatan di layanan PPTP2A. ${ }^{34}$

Dari uraian di atas, diketahui bahwa Pemerintah Kota Surabaya telah berusaha keras dalam melindungi dan memenuhi hak anak warga Surabaya, baik di bidang kesehatan, pendidikan, kesejahteraan sosial maupun sarana prasarana di antaranya berupa pemberian pelatihan, sosialisasi, kampanye, pembinaan dan pendampingan, pemberdayaan, bantuan dan

${ }^{34}$ Ibid. 
apresiasi serta pelibatan dalam berbagai kegiatan. Selain itu, juga berupa penyediaan berbagai fasilitas yang ramah anak serta berbagai lembaga perlindungan anak. hal ini dilakukan agar tumbuh kembang anak berjalan dengan baik, dari segi fisik, mental, moral, intelektual serta kesehatannya.

Dengan demikian, terlihat jelas bahwa Pemerintah Kota Surabaya sangat berperan aktif dalam mewujudkan Kota Layak Anak. Peran tersebut terlihat jelas dari adanya berbagai kebijakan dan program Pemerintah Kota Surabaya yang mendukung penguatan kelembagaan Kota Layak Anak dan pemenuhan kelima klusternya berupa hak sipil dan kebebasan, lingkungan keluarga dan pengasuhan alternatif, kesehatan dasar dan kesejahteraan, pendidikan, pemanfaatan waktu luang dan kegiatan budaya serta perlindungan khusus.

\section{Peran Pemerintah Kota Surabaya dalam Mewujudkan Kota Layak Anak Melalui Kebijakan Publik yang Ditetapkan Perspektif Maqāșid al-Sharī'ah}

Untuk mendapatkan kepercayaan publik, penetapan suatu kebijakan oleh pemerintah harus selalu didasarkan pada kebutuhan masyarakat atau kepentingan masyarakat yaitu dalam rangka mempertahankan dan meningkatkan kualitas kehidupan orang banyak serta mencegah kemungkinan timbulnya kerugian. Konsep ini sejalan dengan konsep Islam yang menempatkan kemaslahatan atas kehidupan manusia sebagai tujuan penetapan sebuah hukum di samping menghindarkan kemadharatan tentunya, yang disebut dengan menggunakan istilah maqāșid al-sharì'ah.

Allah Swt. sebagai pembuat hukum atau shari' tidak menciptakan atau menetapkan aturan atau hukum begitu saja, namun terdapat maksud atau tujuan di dalamnya. Tujuan penetapan tersebut sering dikenal dengan istilah maqāșid alsharī'ah yang merupakan konsep penting pada kajian hukum Islam sehingga harus dipahami oleh mujtahid untuk melakukan ijtihad. ${ }^{35}$

35 Ghofar Shidiq, "Teori Maqashid al-Syari'ah dalam Hukum Islam", dalam Jurnal Sultan Agung, Vol. XLIV, No. 118 (Juni-Agustus, 2019), 117. 
Secara singkat maqāṣid al-sharī'ah sendiri diartikan sebagai tujuan yang ingin dicapai dalam hukum Islam yang telah ditentukan oleh Allah dan Rasul-Nya, yaitu berupa kemaslahatan umat manusia ${ }^{36}$ yang secara umum dibagi menjadi dua bentuk berikut:

1. Mewujudkan kebaikan atau kemanfaatan bagi manusia (jalb al-masalih/jalb al-manafi').

2. Mencegah atau menghindari keburukan dan kerusakan (dar' al-mafasid). ${ }^{37}$

Adapun maslahah sebagai substansi maqāșid al-sharī'ah dapat dibagi menjadi tiga tingkatan, yaitu:

1. Daruriyāt, yaitu maslahah yang bersifat primer yang tidak dapat ditinggalkan karena dapat menimbulkan kehancuran bagi manusia.

2. Hajiyāt, yaitu maslahah yang bersifat sekunder yang dibutuhkan guna memudahkan kehidupan manusia sehingga tidak sampai menimbulkan kerusakan jika ditinggalkan.

3. Taḥsiniyāt, yaitu maslahah yang bersifat tersier yang merupakan tuntutan moral yang dibutuhkan guna peningkatan kualitas kehidupan manusia sehingga tidak menimbulkan kerusakan dan kesulitan apabila ditinggalkan. ${ }^{38}$

Pada setiap tingkatan di atas terdapat lima unsur pokok, yang dikenal dengan usul al-khamsah, dan harus dipelihara atau dijaga guna mewujudkan kemaslahatan, yang meliputi pemeliharaan agama (hifz al-dīn), jiwa (hifz al-nafs), akal (hifz al'aql), keturunan (hifz al-'aql) serta harta (hifz al-māl). ${ }^{39}$ Pemaknaan kelima unsur pokok ini kemudian diperluas oleh

\footnotetext{
${ }^{36}$ Akmaludin Sya'bani, "Maqasid al-Syari'ah sebagai Metode Ijtihad", Elhikam, Vol. VIII, No. 1 (Januari-Juni, 2015), 129-131.

${ }^{37}$ Maman Suherman, “Aliran Ushul Fiqh dan Maqashid Syari'ah”, Al Maslahah Jurnal Hukum dan Pranata Sosial Islam (2017), 362.

${ }^{38}$ Ghofar Shidiq, “Teori Maqashid al-Syari'ah dalam Hukum Islam”..., 122-124.

39 Ridwan Jamal, "Maqashid al-Syari'ah dan Relevansinya dengan Konteks Kekinian”, Al-Syir'ah, Vol. 8, No. 1 (2010), 7.
} 
Jasser Auda,40 hifz al-din diartikan menjadi "kebebasan kepercayaan"; hifz al-nafs menjadi "perlindungan harga diri manusia/hak asasi manusia"; hifz al-'aql menjadi "pengembangan pemikiran ilmiah/perjalanan menuntut ilmu"; hifz al-nasl menjadi "kepedulian pada keluarga"; dan hifz al-mal menjadi "pengembangan ekonomi dan penekanan jurang antarkelas". 41

Jika kebijakan dan progam tersebut dirinci dari sudut pandang maqāșid al-sharī'ah yang memuat kelima unsur pokok yang telah disebutkan sebelumnya, maka berikut analisisnya:

1. Kelembagaan

a. Dari beberapa peraturan Pemerintah Kota Surabaya mengenai penguatan kelembagaan Kota Layak Anak secara tersurat dapat diketahui bahwa terdapat hifz alnafs (pemeliharaan jiwa/diri) dengan penyelenggaran kesehatan dan kesejahteraan sosial, hifz al-nafs (pemeliharaan jiwa/diri) dan hifz al-'aql (pemeliharaan akal) dengan adanya penyelenggaraan administrasi kependudukan serta hifz al-'aql (pemeliharaan akal) dengan adanya penyelenggaraan pendidikan.

b. Dari beberapa program Pemerintah Kota Surabaya dalam rangka penguatan kelembagaan Kota Layak Anak terdapat hifz al-nafs (pemeliharaan jiwa/diri) dan hifz al-'aql (pemeliharaan akal) pada pelibatan FAS di berbagai kegiatan termasuk di dalamnya Kampanye Perlindungan Anak dan Sosialisasi Dinamika Remaja. ${ }^{42}$

2. Kluster I: Hak Sipil dan Kebebasan

a. Dari beberapa peraturan Pemerintah Kota Surabaya mengenai hak sipil dan kebebasan secara tersurat dapat diketahui bahwa terdapat hifz al-nafs (pemeliharaan jiwa/diri) dan hifz al-nasl (pemeliharaan keturunan/keluarga) dengan adanya penyelenggaraan administrasi kependudukan serta hifz al-'aql

\footnotetext{
${ }^{40}$ Arina Haqan, "Rekonstruksi Maqasid al-Syari'ah Jasser Auda", JPIK, Vol. 1, No. 1 (Maret, 2018), 151.

41 Jasser Auda, Maqasid Shari'ah as Philosophy of Islamic Law: A Sistem Aprroarch, terj. Rosidin dan Ali Abd el-Mun'im (Bandung: Mizan, 2015), 320.

${ }^{42}$ Dokumen Jawaban Evaluasi Kota Layak Anak Surabaya.
} 
(pemeliharaan akal) dengan adanya Layanan Informasi Anak,

b. Dari beberapa program Pemerintah Kota Surabaya dalam mewujudkan hak sipil dan kebebasan terdapat hifz al-nafs (pemeliharaan jiwa/diri) dan hifz al-nasl (pemeliharaan keturunan/keluarga) dengan adanya penyelenggaraan administrasi kependudukan secara gratis dan mudah, hifz al-'aql (pemeliharaan akal) dengan berbagai fasilitas ILA Informasi Layanan Anak dan Layanan Telepon Sahabat Anak (TeSa) dengan beragam macamnya.

3. Kluster II: Lingkungan Keluarga dan Pengasuhan Alternatif

a. Dari beberapa peraturan Pemerintah Kota Surabaya mengenai lingkungan keluarga dan pengasuhan alternatif secara tersurat dapat diketahui bahwa terdapat hifz al-'aql (pemeliharaan akal) dengan adanya penyelenggaraan Pendidikan dan PAUD serta Layanan Informasi Anak, hifz al-nafs (pemeliharaan jiwa/diri) dengan adanya penyelenggaraan kesejahteraan sosial dan PPTP2A Kota Surabaya, hifz al-nafs (pemeliharaan jiwa/diri) dan hifz al-'aql (pemeliharaan akal) dengan adanya Liponsos Kalijudan dan Kampung anak Negeri, hifz al-nafs (pemeliharaan jiwa/diri) dan hifz al-nasl (pemeliharaan keturunan/keluarga) dengan adanya Tim Pembinaan Keluarga Sejahtera dan Puspaga Kota Surabaya.

b. Dari beberapa program Pemerintah Kota Surabaya dalam mewujudkan lingkungan keluarga dan pengasuhan alternatif terdapat hifz al-din (pemeliharaan agama) dengan pelaksanaan Program Huring (Shalat Dhuhur Keliling) atau Majlis taklim setelah maghrib, hifz al-nafs (pemeliharaan jiwa/diri) dengan adanya RASS, hifz al-nafs (pemeliharaan jiwa/diri) dan hifz al-'aql (pemeliharaan akal) dengan adanya Lembaga Pengasuhan Alternatif yang terstadarisasi, hifz al-'aql (pemeliharaan akal) dan hifz al-nasl (pemeliharaan keturunan/keluarga) dengan 
adanya lembaga Konseling Keluarga dan Suscatin, hifz al-nasl (pemeliharaan keturunan/keluarga) pada pencegahan perkawinan, serta hifz al-'aql (pemeliharaan akal) dengan adanya PAUD HI dan RBRA.

4. Kluster III: Kesehatan Dasar dan Kesejahteraan

a. Dari beberapa peraturan Pemerintah Kota Surabaya mengenai kesehatan dasar dan kesejahteraan secara tersurat dapat diketahui bahwa terdapat hifz al-'nafs (pemeliharaan jiwa/diri) dengan adanya penyelenggaraan kesehatan, pengelolaan kualitas air dan pengendalian air limbah, Kawasan Tanpa Rokok dan Terbatas Merokok serta Gerakan Masyarakat Hidup Sehat.

b. Dari beberapa program Pemerintah Kota Surabaya dalam mewujudkan kesehatan dasar dan kesejahteraan terdapat hifz al-nafs (pemeliharaan jiwa/diri) dengan adanya pemantauan untuk ibu hamil di Surabaya, penanggulangan permasalahan gizi, penyediaan Ruang ASI dan RSSIB, penyediaan air minum dalam rumah tangga, hifz al-'aql (pemeliharaan akal) dengan adanya beragam pelatihan, seminar, sosialisasi untuk ibu hamil, hifz al-nafs (pemeliharaan jiwa/diri) dan hifz al-'aql (pemeliharaan akal) dengan adanya sosialisasikan kebijakan Kawasan Tanpa Rokok beserta sanksinya dan penyediaannya di berbagai fasilitas serta sosialisasikan bahaya merokok serta penyediaan ruang khusus untuk merokok.

5. Kluster IV: Pendidikan, Pemanfaatan Waktu Luang dan Kegiatan Budaya

a. Dari beberapa peraturan Pemerintah Kota Surabaya tentang pendidikan, pemanfaatan waktu luang dan kegiatan budaya secara tersurat dapat diketahui bahwa terdapat hifz al-'nafs (pemeliharaan jiwa/diri) dengan adanya Kawasan Tanpa Rokok dan Terbatas Merokok serta hifz al-'aql (pemeliharaan akal) dengan adanya penyelenggaraan dan pengelolaan pendidikan dan perpustakaan, perlindungan pohon, retribusi Tempat 
Rekreasi, Olahraga dan Kepariwisataan.

b. Dari beberapa program Pemerintah Kota Surabaya dalam mewujudkan pendidikan, pemanfaatan waktu luang dan kegiatan budaya terdapat hifz al-nafs (pemeliharaan jiwa/diri) dan hifz al-'aql (pemeliharaan akal) dengan adanya penyediaan Kampung Anak Negeri dan Liponsos Kalijudan dan Lembaga Pengasuhan Alternatif di Kota Surabaya serta hifz al-'aql (pemeliharaan akal) dengan pengadaan program BLC (Board Learning Center), Sosialisasi Dinamika Remaja, Sekolah Ramah Anak (SRA), pembentukan PKA (Pusat Kreatifitas Anak).

6. Kluster V: Perlindungan Khusus

a. Dari beberapa peraturan Pemerintah Kota Surabaya mengenai perlindungan khusus secara tersurat dapat diketahui bahwa seluruhnya memuat adanya hifz alnafs (pemeliharaan jiwa/diri) dari berbagai hal di antaranya pencegahan terhadap perdagangan orang, penanggulangan HIV/AID, Bencana Saat Tanggap Darurat di Kota Surabaya.

b. Dari beberapa program Pemerintah Kota Surabaya dalam mewujudkan perlindungan khusus terdapat hifz al-nafs (pemeliharaan jiwa/diri) dengan adanya penyedian jalur evakuasi ramah anak, pelaksanaan razia pekerja anak dan peningkatan kesejahteraan anak penyandang disabilitas, hifz al-nafs (pemeliharaan jiwa/diri) dan hifz al-'aql (pemeliharaan akal) dengan adanya pemberian kesempatan, partisipasi dan apresiasi terhadap anak penyandang disabilitas, pembinaan melalui Kampunge Arek Surabaya dan Kampung Anak Negeri, penyediaan lembaga layanan untuk anak sebagai korban, baik korban kekerasan, penelantaran, pornografi, pekerjaan terburuk, penyalahgunaan Napza, terinfeksi HIV/AIDS serta korban bencana dan konflik stigmatisasi atas kondisi orang tuanya,.

Selain itu, terdapat juga hifz al-'aql (pemeliharaan 
akal) dengan adanya pembentukan Sekolah atau Madrasah Siap Bencana yang dilakukan oleh Satlak PB dan penguatan pendidikan Pancasila dan rasa cinta tanah air guna pencegahan anak menjadi korban jaringan terorisme, pembentukan kader anti kenakalan remaja dan konselor sebaya serta Puspaga (Pusat Pembelajaran Keluarga), penyediaan sistem pelaporan dan pencatatannya anak sebagai korban, kampanye, sosialisasi, pendampingan dan pendampingan.

Dari pemaparan analisis di atas, maka dapat disimpulkan, bahwa kebijakan publik yang ditetapkan oleh Pemerintah Kota Surabaya dalam mewujudkan Kota Layak Anak telah sesuai maslahah karena semua kebijakan publik tersebut mengandung unsur kebaikan guna pemenuhan hak anak warga Kota Surabaya dengan juga menghindarkan keburukan yang akan didapatkan olehnya.

Semua kebijakan publik tersebut juga sesuai dengan unsur pokok yang menjadi tujuan penetapan hukum (maqāṣid alshari'ah) dengan beragam tingkat kebutuhannya, baik daruriyat (primer), hajiyāt (skunder) dan tahssiniyāt (tersier) dengan rincian sebagai berikut:

1. Dalam kebijakan publik mengenai kelembagaan terkandung hifz al-nafs (pemeliharaan jiwa/diri) dan hifz al-'aql (pemeliharaan akal).

2. Dalam kebijakan publik mengenai kluster I: hak sipil dan kebebasan terkandung hifz al-nafs (pemeliharaan jiwa/diri), hifz al-'aql (pemeliharaan akal) dan hifz al-nasl (pemeliharaan keturunan/keluarga).

3. Dalam kebijakan publik mengenai kluster II: lingkungan keluarga dan pengasuhan alternatif terkandung hifz al-din (pemeliharaan agama), hifz al-nafs (pemeliharaan jiwa/diri), hifz al-'aql (pemeliharaan akal) dan hifz al-nasl (pemeliharaan keturunan/keluarga).

4. Dalam kebijakan publik mengenai kluster III: kesehatan dasar dan kesejahteraan terkandung hifz al-nafs (pemeliharaan jiwa/diri) dan hifz al-'aql (pemeliharaan akal). 
5. Dalam kebijakan publik mengenai kluster IV: Pendidikan, pemanfaatan waktu luang dan kegiatan budaya terkandung hifz al-nafs (pemeliharaan jiwa/diri) dan hifz al-'aql (pemeliharaan akal

6. Dalam kebijakan publik mengenai kluster V: Perlindungan khusus terkandung hifz al-nafs (pemeliharaan jiwa/diri) dan hifz al-'aql (pemeliharaan akal).

Adapun dari kelima unsur pokok yang ada, unsur hifz \{ alnafs (pemeliharaan jiwa/diri), hifz al-'aql (pemeliharaan akal), kemudian hifź al-nasl (pemeliharaan keturunan/keluarga) yang banyak terkandung dalam kebijakan maupun program Pemerintah Kota Surabaya dalam mewujudkan Kota Layak Anak. Adapun secara tersurat terdapat dua program Pemerintah Kota Surabaya tersebut yang mengandung hifz\{ al-din (pemeliharaan agama). Akan tetapi jika diteliti lebih jauh secara tersirat unsur hifz al-din (pemeliharaan agama) ini akan ditemukan juga pada kluster I yaitu hak sipil dan kebebasan, yang mana makna kebebasan disini juga termasuk kebebasan beragama.

Dengan demikian, dapat disimpulkan bahwa terdapat unsur hifz al-din (pemeliharaan agama) dan hifz al-nasl (pemeliharaan keturunan/keluarga) pada kebijakan publik mengenai kluster II (hak sipil dan kebebasan) serta kluster III (lingkungan keluarga dan perlindungan alternatif) dan unsur hifz al-nafs (pemeliharaan jiwa/diri) dan hifz al-'aql (pemeliharaan akal) pada kebijakan publik mengenai penguatan kelembagaan dan kelima kluster Kota Layak Anak.

Adapun mengenai tidak ditemukannya secara tersurat hifz al-māl (pemeliharaan harta) pada kebijakan dan program Pemerintah Kota Surabaya dalam Mewujudkan Kota Layak Anak dan tidak juga secara tersirat karena posisi anak di sini masih dalam tanggung jawab pengasuhan orang tuanya termasuk di dalamnya membiayai segala macam kebutuhannya dengan tetap memperhatikan kemampuan tentunya. Kalaupun anak tersebut memiliki harta, dia tetap terikat pada orang tua/walinya dalam hal pen-tașarruf-an harta yang dimilikinya tersebut. Pernyataan ini agaknya dikuatkan dengan adanya pelarangan/pembatasan 
atas pekerja anak karena dapat mengganggu tumbuh kembangnya, baik fisik, mental, moral, intelektual maupun kesehatannya.

Oleh karena itu, dalam upaya perlindungan dan pemenuhan hak-hak anak, Pemerintah Kota Surabaya seharusnya tetap memperhatikan juga unsur hifz al-mal (pemeliharaan harta) untuk selanjutnya baik ditetapkan dalam kebijakan maupun programnya agar kesejahteraan anak dapat lebih terjamin dan kehidupannya semakin sempurna dengan terpenuhinya kelima unsur pokok yang terdapat dalam maqāssid al-sharī'ah. Selain itu, Pemerintah Kota Surabaya harus terus memperbaiki dan meningkatkan segala upaya perlindungan serta pemenuhan hak-hak anak agar terus mampu menyandang predikat Kota Layak Anak dari Kementerian Pemberdayaan Perempuan dan Perlindungan Anak serta menjadi percontohan bagi Kabupaten/Kota lain dalam upaya untuk mewujudkan Kabupaten/Kota Layak Anak.

\section{Penutup}

Pemerintah Kota Surabaya sangat berperan aktif dalam mewujudkan Kota Layak Anak melalui perlindungan dan pemenuhan hak-hak anak yang terlihat jelas dari berbagai kebijakan publik yang ditetapkan guna mendukung penguatan kelembagaan Kota Layak Anak dan pemenuhan kelima klusternya berupa hak sipil dan kebebasan, lingkungan keluarga dan pengasuhan alternatif, kesehatan dasar dan kesejahteraan, pendidikan, pemanfaatan waktu luang dan kegiatan budaya serta perlindungan khusus.

Peran Pemerintah Kota Surabaya dalam mewujudkan Kota Layak Anak melalui kebijakan publik yang ditetapkan telah sesuai dengan konsep maqāșid al-sharï'ah karena penetapan kebijakan publik tersebut berdasarkan pada kemaslahatan anak yang terbukti dengan terkandungnya unsur hifz al-din (pemeliharaan agama) serta hifz al-nasl (pemeliharaan keturunan/keluarga) pada kebijakan publik mengenai hak sipil dan kebebasan serta lingkungan keluarga dan perlindungan alternatif dan unsur hifz al-nafs (pemeliharaan jiwa/diri) serta hifz al-'aql (pemeliharaan akal) pada kebijakan publik mengenai 
penguatan kelembagaan dan kelima kluster Kota Layak Anak, meskipun sebenarnya kurang sempurna karena ketiadaan unsur hifz al-mal (pemeliharaan harta) di dalamnya.

\section{Daftar Pustaka}

Aisyah. "Partisipasi Masyarakat dalam Mewujudkan Kampung Ramah Anak melalui Program Inisiasi Kampunge Arek Suroboyo (Kas) di Kelurahan Jambangan Kecamatan Jambangan Kota Surabaya (Studi Pada Rt 7 dan Rt 8 Rw 3 Kelurahan Jambangan Kecamatan Jambangan Kota Surabaya)". Publika, No. 3, Vol. 5, 2017.

Auda, Jasser. Maqasid Shari'ah as Philosophy of Islamic Law: A Sistem Aprroarch, terj. Rosidin dan Ali Abd el-Mun'im. Bandung: Mizan, 2015.

Dialistiowati. "Inovasi Pelayanan Lamongan Sebagai Kota Layak Anak". Skripsi--UIN Sunan Ampel Surabaya, 2017.

Ghofar Shidiq, "Teori Maqashid al-Syari'ah dalam Hukum Islam", dalam Jurnal Sultan Agung, Vol. XLIV, No. 118, JuniAgustus, 2019.

Haqan, Arina. "Rekonstruksi Maqasid al-Syari'ah Jasser Auda". JPIK, Vol. 1, No. 1, Maret, 2018.

Investor Daily Indonesia. "Membangun Kota Layak Anak", dalam http://id.beritasatu.com/home/membangun-kotalayak-anak/16543, diakses pada 17 September 2018.

Jamal, Ridwan. "Maqashid al-Syari'ah dan Relevansinya dengan Konteks Kekinian”. Al-Syir'ah, Vol. 8, No. 1, 2010.

Kementerian Pemberdayaan Perempuan dan Perlindungan Anak. Petunjuk Teknis Indikator Kabupaten/Kota Layak Anak 2019. Jakarta: Kementerian Pemberdayaan Perempuan dan Perlindungan Anak, 2019.

Khallaf. 'Abd al-Wahhab. 'Ilm Usul al-Fiqh, terj. Faiz el Muttaqin. Jakarta: Pustaka Amani, 2003.

Kla.id. "Definisi KLA dan Kluster", dalam http://www.kla.id/, diakses pada 01 Oktober 2019.

Koran Jakarta. "Upaya Risma Jadikan Surabaya Kota Layak Anak, dalam http://www.koran-jakarta.com/upaya-rismajadikan-surabaya-kota-layak-anak/, diakses pada 29 Mei 2019. 
Kurniawan, Miftakhul Prastya. "Implementasi Kebijakan Kota Layak Anak (Studi Deskriptif Tentang Kluster Perlindungan Khusus di Kota Surabaya)". Skripsi-Universitas Airlangga, 2016.

Kusumastuti, Merdina. "Implementasi Kebijakan

Pengarusutamaan Hak Anak dalam Rangka Mewujudkan Kabupaten Layak Anak (Studi Pada Badan Pemberdayaan Perempuan dan Keluarga Berencana Kabupaten Jombang)". Jurnal Administrasi Publik, No. 6, Vol. 1, 2013.

Margono-Surya Partners. "Perlindungan Anak, dalam file://D:/Penelitian\%20Baru/Margono\%20 \%20Sury a\%20\&\%20Partners\%20Perlindungan\%20Anak\%20-\% 20Margono\%20 \%20Surya\%20\&\%20Partners.html, diakses pada 17 September 2018.

Munir, Fatchul (Tim Pembina Keluarag Puspaga (Pusat Pembelajaran Keluarga) DP5A Kota Surabaya). Wawancara. Surabaya, 4 Oktober 2019.

Safitri, Faradilla Nissa. "Implementasi Kebijakan Pengembangan Kota Layak Anak di Kecamatan Semampir Surabaya". Publika, No. 3, Vol. 4, 2013.

Okezone News. "Surabaya dan Solo Pertahankan Gelar Kota Layak Anak", dalam https://news.okezone.com/read/2018/07/24/1/19265 01/surabaya-dan-solo-pertahankan-gelar-kota-layakanak, diakses pada 17 September 2018.

Parenting Indonesia. "Mengintip Surabaya Kota Layak Anak", dalam http://www.parenting.co.id/keluarga/mengintipsurabaya-kota-layak-anak-, diakses pada 17 September 2018.

Pemerintah Kota Surabaya. "The History of Surabaya”, dalam https://sparkling.surabaya.go.id/about/the-history-ofsurabaya/, diakses pada 04 April 2020.

Praptama, Amdany (Staf Bidang Pengarusutamaan Hak Anak (Puha) DP5A Kota Surabaya). Wawancara. Surabaya, 1 Oktober 2019. 
Suherman, Maman. "Aliran Ushul Fiqh dan Maqashid Syari'ah".

Al Mahlahah Jurnal Hukum dan Pranata Sosial Islam (2017), 362.

Sya'bani, Akmaludin. "Maqasid al-Syari'ah sebagai Metode Ijtihad". Elhikam, Vol. VIII, No. 1, Januari-Juni, 2015.

Syarifuddi, Amir. Ushul Fiqh, jilid 2. Jakarta: Kencana, 2011.

Dokumen Jawaban Evaluasi Kota Layak Anak Surabaya.

Peraturan Menteri Negara Pemberdayaan Perempuan dan

Perlindungan Anak Republik Indonesia tentang

Kebijakan Pengembangan Kabupaten/Kota Layak Anak.

Undang-undang Dasar 1945 (Perubahan Kedua).

Undang-undang Nomor 35 Tahun 2014 tentang Perubahan Atas

Undang-undang Nomor 23 Tahun 2002 tentang Perlindungan Anak. 